African Crop Science Journal by African Crop Science Society is licensed under a Creative Commons Attribution 3.0 Uganda License. Based on a work at www.ajol.info/ and www.bioline.org.br/cs

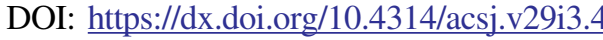

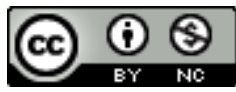

\title{
IMPROVED CALLOGENESIS AND PLANT REGENERATION FROM IMMATURE MALE FLOWERS OF EAST AFRICAN HIGHLAND BANANA CV. "NAKITEMBE" (AAA-EA)
}

\author{
D. TALENGERA ${ }^{1,2}$, C. MWAMI ${ }^{1}$, A.F. TAZUBA ${ }^{1,3}$ and B. NAMUKWAYA ${ }^{1,4}$ \\ 'National Agricultural Research Laboratories, P.O. Box 7065, Kampala-Uganda \\ ${ }^{2}$ Present address: Department of Agriculture, Ndejje University, P. O. Box 7088, Kampala, Uganda \\ ${ }^{3}$ Present address: International Institute of Tropical Agriculture-Uganda, P. O. Box 7878, \\ Kampala, Uganda \\ ${ }^{4}$ Present address: Agriculture Unit, Office of the President P. O. Box 7168 Kampala, Uganda \\ Corresponding author: dtalengera@ndejjeuniversity.ac.ug, davidtalengera50@ gmail.com
}

(Received 30 June 2021; accepted 24 August 2021)

\begin{abstract}
Application of biotechnological tools in breeding, germplasm conservation and propagation of the East African bananas (Musa sp.) is limited by the crop's recalcitrance to somatic embryogenesis. This study was undertaken to establish an efficient callus induction and plant regeneration protocol from immature male flowers in the most commercial and farmer preferred banana cultivar "Nakitembe". Embryogenic callusing was improved from $2.9 \%$ on conventional MA1 culture medium to $4.2 \%$ with $500 \mathrm{mg} \mathrm{L}^{-1}$ L-Glutamine, $500 \mathrm{mg} \mathrm{L}^{-1} \mathrm{~L}$-Proline and $300 \mathrm{mg} \mathrm{L}^{-1}$ casein hydrolysate supplements. A combination of the three amino acids with Chui N6 salts yielded the highest callusing of 10.2\%. Cell suspensions were developed and maintained on conventional MS based MA2 medium. Subsequently, the highest efficiency of embryos germination (up to 80\%) was achieved on MA4 medium, supplemented with $2.25 \mathrm{mg} \mathrm{L}^{-1} \mathrm{BAP}$ and $0.2 \mathrm{mg} \mathrm{L}^{-1}$ IAA. The developed protocol has been successfully applied in Agrobacterium mediated genetic transformations of this variety.
\end{abstract}

Key Words: Agrobacterium, embryogenic callus, male flowers, Musa sp.

\section{RÉSUMÉ}

L'application des outils biotechnologiques dans la sélection, la conservation du matériel génétique et la propagation des bananiers d'Afrique de l'Est (Musa sp.) est limitée par la réticence de la culture à l'embryogenèse somatique. Cette étude a été entreprise pour établir un protocole efficace d'induction des cals embryogènes et de régénération des plantes à partir de fleurs mâles immatures dans le cultivar de bananier le plus commercial et préféré des agriculteurs « Nakitembe ». Les callosités embryogènes ont été améliorées de 2,9\% sur le milieu de la culture MA1 conventionnel à 4,2\% avec des suppléments de $500 \mathrm{mg} \mathrm{L}^{-1} \mathrm{~L}$-Glutamine, $500 \mathrm{mg} \mathrm{L}^{-1} \mathrm{~L}$-Proline et $300 \mathrm{mg} \mathrm{L}^{-1}$ d'hydrolysat de caséine. Une combinaison des trois acides aminés avec des sels de Chui N6 a donné le cal embryogène le plus élevé de 10,2\%. 
Des suspensions cellulaires ont été développées et maintenues sur un milieu MA2 à base de MS conventionnel. Par la suite, l'efficacité la plus élevée de la germination des embryons (jusqu'à $80 \%$ ) a été obtenue sur le milieu MA4 complété par 2,25 $\mathrm{mg} \mathrm{L}^{-1}$ de BAP et $0,2 \mathrm{mg} \mathrm{L}^{-1}$ d'IAA. Le protocole développé a été appliqué avec succès dans les transformations génétiques induites par Agrobacterium de cette variété.

Mots Clés : Agrobacterium, cal embryogène, fleurs mâles, Musa sp.

\section{INTRODUCTION}

The need to address the aggressive climate change phenomena, evolution of pathogens as well as meet human nutritional requirements, calls for efforts that widen the genetic base of staple crops. For the East African highland bananas, conventional breeding that was initiated in 1993, has yielded so far three hybrids that are resistant to Black sigatoka (Mycosphaerella fijiensis), corm borer (Cosmopilites sordidus Germar) and burrowing root nematode (Radopholus similis) (Nowakunda et al., 2015; Tumuhimbise et al., 2016). This success is attributed to a few seed fertile varieties (Ssebuliba et al., 2006), representing only $3 \%$ of the diversity of the East African highland germplasm. Furthermore, this achievement has been through a painstakingly long selection duration, characterised by discarding of large amounts of materials, carryover of non-pathenocarpic attributes from the male parents and hybrids that could not meet the desirable consumer fruit quality (Pillay et al., 2004).

Accordingly, transgenic technology that enables transfer of genes across cultivars and species becomes of great value to circumvent the barriers to conventional breeding in banana. Agrobacterium-mediated genetic engineering, which is so far the most efficient process of introgressing desirable genes into plant varieties, requires an efficient cell suspension system (Dai et al., 2001; Arinaitwe et al., 2004). The benefit of single cell protocol is that plants generated from them are not chimeric (Strosse et al., 2003).

Universal Musa cell culture goes through two phases (Strosse et al., 2003). First, highly meristematic tissue termed as "scalps" is attainable through prolonged culturing of shoot meristems on high cytokinin (6benzyladeninepurine) concentrations. This is followed by culturing the scalps on a strong auxin, mainly 2,4-D, to induce callus. However, long consecutive exposure of tissues to high levels of potent growth regulators poses a risk of somaclonal variations (Hu et al., 2008). In contrast, immature male flowers buds provide a ready meristematic tissue that requires balanced growth regulators to induce callus formation. Low exposure of plant tissues to growth regulators reduces the risk of destabilising the banana genome (Hu et al., 2008). In addition, the perennial nature of the banana plant ensures all year-round availability of flower explants. The flowers are also sterile and require less preparation for in vitro initiation.

Application of immature male flowers in somatic embryogenesis has been recorded in a range of Musa genomes and ploidy levels: $\mathrm{AA}, \mathrm{AB}, \mathrm{AAA}, \mathrm{AAB}$ and $\mathrm{AAAB}$ (Xu et al., 2008; Youssefet al., 2010; Elayabalan et al., 2013). To date, success with the male flower culture method on the highland banana group (genome AAA-EA) has been reported in one cooking cultivar "Nakyetengu" (Namanya et al., 2004). This coverage is very minimal, given the diversity of this banana group estimated at over 80 varieties (Karamura, 1999) and the importance of the crop as a staple and income source in the East African region.

Traditional callus induction nutrient medium for banana has been Murashige and Skoog (MS) (1962) basal salts used together with 2,4-Dichlorophenoxyacetic acid (2,4-D), 
indole-3-Acetic Acid (IAA), Naphtalelene Acetic acid (NAA) and biotin. However, fortification with organic compounds such as glutamine, malt extract and proline in callus induction media have been reported for different banana genome and cultivar (Strosse et al., 2003; Elayabalan et al., 2013). Therefore, the highland banana's recalcitrance to somatic embryogenesis required deviating from the traditional callus induction medium by exploring potent salts and organic compounds. A final step in embryogenesis system is to efficiently convert the cell suspensions into plantlets. Reports show callus formation and regeneration responses in banana to be varied and genome dependent (Strosse et al., 2003; Hu et al., 2008). This study was undertaken to establish an efficient callus induction and plant regeneration protocol from immature male flowers in one of the most commercial and farmer preferred East African highland banana cultivar "Nakitembe".

\section{MATERIALS AND METHODS}

This study was conducted during 2012-2017, at the National Agricultural Research Laboratories- Kawanda (NaRL), a research centre of the National Agricultural Research Organisation of Uganda.

Plant material. An East African cooking banana cultivar "Nakitembe" (genome AAAEA) was studied. Male buds were collected after full opening of all the female flowers on the bunch. Outer bracts were removed to reduce the male bud to $5 \mathrm{~cm}$, and the bud surface sterilised by a $5 \mathrm{~min}$ dip in $70 \%$ ethanol. More bracts were removed to expose the immature flowers. From each bud, twelve immature flowers, counting towards the tip of the male bud, were isolated under a dissecting microscope and working aseptically in a laminar flow hood. Flowers were inoculated on culture nutrient medium in an upright position.
Induction of embryogenic callus. After failure to consistently obtain embryogenic callus on the culture medium that has been used by several researchers on different banana genotypes, and hence termed "standard" (Strosse et al., 2003), we adjusted this medium for the highland banana by adapting the macro elements of Chu- $\mathrm{N}_{6}(\mathrm{Chu}$ et al.,1975). The medium was reinforced with amino acids, glutamine and L-Proline, and casein hydrolysate together with a cytokinin (kinetin) (Table 1).

Regeneration of plantlets. Three cell suspension lines coded 660, 745 and 732, according to their sequence of generation and which had been maintained in liquid medium MA2 for 43, 33 and 25 months, respectively, were used for the regeneration experiment. Organogenesis studies were prompted by the very low conversion of the embryos into shoots on the standard embryo development medium, MA3 (Strosse et al., 2003) and observed reversion of some embryos into callus instead of regenerating into shoots. Working under antiseptic conditions, a half millilitre of packed cell volume (PCV) of cells was aspirated with a wide pipette tip and uniformly spread on sterile nylon meshes and plated on embryo development medium (MA3) composition (Table 1). Cultures were transferred to fresh medium bi-weekly, until the embryos matured.

Thirty embryos were randomly picked and distributed on a culture plate, containing the experimental embryo germination media (MA4), with varied 6-benzyladenine purine (BAP) and indole acetic acid (IAA) concentrations (Table 2). Each treatment consisted of 6 plates on which germination response was monitored weekly.

Culture media preparation. All media were bulk autoclaved at $121{ }^{\circ} \mathrm{C}$ and pressure of 103.4 KPa. With the exception of auxin 2,4$\mathrm{D}$, all growth regulators were filter sterilised 
TABLE 1. Composition of media used for callus induction and embryo germination of cv "Nakitembe"

Media Composition

MA1 $^{\text {a }}$ (Ma embryogenic callus induction medium)

MS2 (Fortified MS medium)

B6 (Fortified N6 medium)

B61 (Fortified N6 medium plus 0.25 Kinetin)

B62 (Fortified N6 medium plus 0.5 Kinetin)

MA2 (Cell suspension culture medium)

MA3 (Embryo formation medium)

MA4 ${ }^{\mathrm{b}}$ (Experimental embryo germination medium)

Shoot elongation medium
MS (Murashige and Skoog) macros, MS micros \& MA vitamins*, (mg L $\left.{ }^{-1}\right): 20$ ascorbic acid; (1) Biotin; (1) 2,4-D; (1) IAA; (1) NAA; $30 \mathrm{~g} \mathrm{~L}^{-1}$ Sucrose; $3.0 \mathrm{~g} \mathrm{~L}^{-1}$ Gelrite; $\mathrm{pH} 5.7$

MS macros, MS micros and MA vitamins*, $\left(\mathrm{mg} \mathrm{L}^{-1}\right)$ : (500) L-Glutamine; (500) L-proline; (300) Casein hydrolysate (1) 2,4-D; (1) IAA; (1) NAA; $30 \mathrm{~g} \mathrm{~L}^{-1}$ Sucrose; $3.0 \mathrm{~g} \mathrm{l}^{-1}$ Gelrite; $\mathrm{pH} 5.7$

Chu $\left(\mathrm{N}_{6}\right)$ macros, MS micros and B5 vitamins $* *\left(\mathrm{mg} \mathrm{L}^{-1}\right)$ : (20) ascorbic acid; (500) L-Glutamine; (500) L-proline; (300) Casein hydrolysate; (1) 2,4-D, (1) IAA, (1) NAA, $30 \mathrm{~g} \mathrm{l}^{-1}$ Sucrose, $2.3 \mathrm{~g} \mathrm{~L}^{-1}$ Gelrite, pH 5.8

Chu ( $\left.\mathrm{N}_{6}\right)$ macros, MS micros and B5 vitamins** (mg L-1): (20) ascorbic acid; (500) L-Glutamine; (500) L-proline; (300) Casein hydrolysate; (1) 2,4-D; (1) IAA; (1) NAA; (0.25) Kinetin; $30 \mathrm{~g} \mathrm{l}^{-1}$ Sucrose; $2.3 \mathrm{~g} \mathrm{~L}^{-1}$ Gelrite; $\mathrm{pH} 5.8$

Chu $\left(\mathrm{N}_{6}\right)$ macros, MS micros and B5 vitamins** (mg L $\left.{ }^{-1}\right)$ : (20) ascorbic acid; (500) L-Glutamine; (500) L-proline; (300) Casein hydrolysate; (1) 2,4-D; (1) IAA; (1) NAA; (0.5) Kinetin; $30 \mathrm{~g} \mathrm{~L}^{-1}$ Sucrose; $2.3 \mathrm{~g} \mathrm{~L}^{-1}$ Gelrite; $\mathrm{pH} 5.8$

MS macros; MS micros; MA vitamins* (mg L-1): (20) Ascorbic acid; (1) 2,4-D; $4.5 \mathrm{~g} \mathrm{~L}^{-1}$ Sucrose; $2.4 \mathrm{~g} \mathrm{l}^{-1}$ Gelrite; $\mathrm{pH} 5.3$

S.H macro and micro salts, MA vitamins*, $\left(\mathrm{mg} \mathrm{L}^{-1}\right)$ : (100) L-Glutamine, (230) L-Proline, (100) Malt extract, (0.2) NAA, (0.05) Zeatin, (0.2) 2ip, (0.2) Kinetin; pH 5.3

MS macros, MS micros and Morel vitamins***, $\left(\mathrm{mg} \mathrm{L}^{-1}\right)$ : (20) Ascorbic acid; $30 \mathrm{~g} \mathrm{~L}^{-1}$ Sucrose;

$2.4 \mathrm{~g} \mathrm{~L}^{-1}$ Gelrite; $\mathrm{pH}$ 5.8. BAP and IAA concentrations were varied in the experiment

MS macros, MS micros and MS vitamins**, $\left(\mathrm{mg} \mathrm{L}^{-1}\right)$ : (20) ascorbic acid; (1) Biotin; (2.5)

BAP; $30 \mathrm{~g} \mathrm{~L}^{-1}$ Sucrose; $3.0 \mathrm{~g} \mathrm{~L}^{-1}$ Gelrite; $\mathrm{pH} 5.7$

${ }^{\mathrm{a}} \mathrm{Ma}$, 1991culture medium composition

*MA1 = Ma vitamins (mg L-1 $)$ : (1) Biotin, (100) myo-inositol, (2) Glycine, (0.5) Nicotinic acid, (0.5) Pyridoxine, (0.1) Thiamine

**B5 (Gamborg) vitamins (mg L-1): (100) myo-inositol, (1) Nicotinic acid, (1) Pyridoxine, (10) Thiamine

***Morel (Morel and Wetmore, 1951) vitamins: (mg L $\left.{ }^{-1}\right)$ : (1) Calcium penthotenate; (0.01) Biotin, (100) myo-inositol, (1) Nicotinic acid, (1) Pyridoxine,

(1) Thiamine

${ }^{a}$ embryogenic callus induction medium whose composition was adjusted

${ }^{\mathrm{b}}$ Embryo germination medium where growth regulator concentrations were varied 
TABLE 2. Growth regulator combinations used in the experimental embryo germination media

\begin{tabular}{lcrrrrrrrrr}
\hline Growth regulators $\left(\mathrm{mg} \mathrm{L}^{-1}\right)$ & Control & \multicolumn{10}{c}{ Treatments of varied BAP and IAA concentrations } \\
\cline { 3 - 11 } & & 1 & 2 & 3 & 4 & 5 & 6 & 7 & 8 & 9 \\
\hline \multirow{2}{*}{ BAP } & 0.5 & 1.12 & 1.12 & 1.12 & 2.25 & 2.25 & 2.25 & 4.5 & 4.5 & 4.5 \\
IAA & 2.0 & 0.0 & 0.1 & 0.2 & 0.0 & 0.1 & 0.2 & 0.0 & 0.1 & 0.2 \\
\hline
\end{tabular}

through a $0.42 \mu \mathrm{m}$ pore size membrane and added to autoclaved media after cooling it to $40{ }^{\circ} \mathrm{C}$. Culture media was dispensed into 90 $\mathrm{cm}$ diameter petri dishes. The media and respective adjustments as used in the study are listed in Table 1.

Culture conditions. Callus cultures, cell suspensions and regeneration cultures were maintained in darkness at $28 \pm 1{ }^{\circ} \mathrm{C}$ and $65-67 \%$ relative humidity. For callus induction, cultures were maintained on the same media until callus appeared. Callus responses were monitored monthly. After the second month of culture, subsequent observations were made fortnightly. Cultures that showed friable calli with at least an embryo were transferred and maintained in liquid medium (MA2) composition (Table 1) according to Strosse et al. (2003). Callus was made to disperse into cell suspension by continuous agitation on a shaker at $190 \mathrm{rpm}$. The cell suspension was started in $5 \mathrm{ml}$ of liquid medium and this was refreshed weekly. The volume of the media was gradually increased as the cell volume increased. At each change of medium, the cell suspension was allowed to settle and the supernatant drown off. The remaining cell volume was topped up with the same volume of fresh medium. For old cultures, five times volume of new fresh medium was used.

Shoot elongation. Shoots that regenerated on MA4 (Strosse et al., 2003) were cultured on shoot elongation medium (Table 1). Cultures were maintained under 2000 Lux of light provided by white fluorescent tubes, at 16:8 photo period. Elongation and rooting of the shoots was achieved on hormone free MS basal salts and vitamins, $30 \mathrm{~g}$ sucrose, ascorbic acid at $20 \mathrm{mg} \mathrm{L}^{-1}$ and gelrite at $2.4 \mathrm{~g} \mathrm{~L}^{-1}$ (Table 1). Rooted shoots were finally transferred to the screen house for acclimatisation.

Data collection and analysis. Callus induction was continuously initiated in 12 repeats with total flowers indicated in Table 2. Parameters recorded were: total number of flower buds initiated, buds that produced callus (based on callus types and embryos presence) and position of the responsive flower. Callus induction frequency (CIF) was calculated as:

$\mathrm{CIF}=$ (number of male buds in which at least a flower produced calli out of the number of male buds plated) $\times$ 100.

Regeneration was scored as the resultant shoots with at least two leaves per cultured embryo. Data were subjected to analysis of variance (ANOVA) and significant means were separated using Fisher's protected least significances difference (LSD) at 5\% level. All experiments were arranged in a completely randomised design.

\section{RESULTS AND DISCUSSION}

Induction of callus. Callusing varied dramatically with the media composition (Table 3). Murashige and Skoog (MS) based medium gave $2.9 \%$ callusing, while fortifying this medium with L-glutamine, L-proline and casein hydrolysate increased the response to 
TABLE 3. Embryogenic callus response in banana cultivar "Nakitembe" across different media

\begin{tabular}{lcccc}
\hline Medium & $\begin{array}{c}\text { No. of male } \\
\text { buds initiated }\end{array}$ & $\begin{array}{c}\text { Male buds producing } \\
\text { embryogenic callus }\end{array}$ & $\begin{array}{c}\text { Callusing } \\
\text { frequency }(\%)\end{array}$ & $\begin{array}{c}\text { Responsive } \\
\text { flower position }\end{array}$ \\
\hline MA1 & 102 & 3 & 2.9 & $8-15$ \\
MS2 & 95 & 4 & 4.2 & $8-15$ \\
B6 & 107 & 11 & 10.2 & $8-15$ \\
B61 & 351 & 5 & 1.4 & $11-15$ \\
B62 & 22 & 1 & 4.5 & 11 \\
\hline
\end{tabular}

4.2\%. Supplementing Chui's N6 based medium (B6) with these amino acids resulted into the highest frequency $(10.2 \%)$. Although Murashige and Skoog medium is popular for in vitro culture, it is not always optimum for some plant culture responses. In fact Pierik (1987) recommended it as a first line medium when the nutrient requirements of a plant species are not known. The superiority of Chui's N6 medium could be explained on the basis of $\mathrm{pH}$ stabilisation by the $\mathrm{NO}_{3}{ }^{-}$and $\mathrm{NH}_{4}{ }^{+}$ ions. A higher ratio of nitrate to ammoniacal nitrogen of $4: 1$ in N6 salts provides better buffering compared to the ratio of $2: 1$ in MS salts based medium (George, 1993). Under buffered culture conditions, the organic nitrogen supplements become beneficial to provide adequate supply of nitrogen required for cell division (Pierik, 1987).

Establishment and maintenance of cell suspensions. Browning of the suspension was a major challenge during the first 4 weeks of establishing the cell suspensions. Browning arises from production of reactive oxygen species (ROS) by cells and from exudates produced by the flower tissue remnants during callus transfer. Both sources of browning are toxic to cells. This problem was, however, solved by incorporation of $20 \mathrm{mg} \mathrm{L}^{-1}$ ascorbic acid into the medium. Ascorbic acid acts by quenching the ROS (Sharma et al., 2012) and by inhibiting polyphenol oxidase enzyme responsible for oxidising cell exudates into the visible black quinones (Ali et al., 2015). Successful cell suspensions consisted of embryogenic round and starch packed cells that have embryogenic properties (Fig. 1).

Conversion of the cells into plantlets. Cell suspensions developed into embryos after they were plated on the solidified regeneration medium (MA3) (Table1). This embryogenesis step (Strosse et al., 2003; Namanya et al., 2004) was therefore not limiting in the somatic embryogenesis protocol of cultivar "Natikembe". Further transfer of the formed somatic embryos to MA4 medium fortified with 6-Benzyladeninepurine (BAP) and IAA at 0.5 and $2 \mathrm{mg} \mathrm{L}^{-1}$, significantly $(\mathrm{P}<0.0001)$ resulted into $7 \%, 9 \%$ and $14 \%$ germination in the old cell line 660, young cell lines 732 and 745, respectively (Figs. 2 and 3). This germination rate was low compared to $22.5 \%$ reported in cultivar "Grand Naine" (Youssef et al., 2010). However, raising cytokinin and auxin concentrations and ratios improved $(\mathrm{P}=0.0152)$ embryo germination, with varied responses. A combination of $2.25 \mathrm{mg} \mathrm{L}^{-1} \mathrm{BAP}$ and $0.2 \mathrm{mg} \mathrm{L}^{-1}$ IAA gave the highest $(\mathrm{P}<0.0001)$ germination rates of 30,60 and $70 \%$ in the respective cell lines 660, 732 and 745 (Fig. 2). These results were comparable to the $65 \%$ embryo regeneration reported in cultivar "Nakinyika" (Namanya et al., 2004). The higher ratio of BAP to IAA of 9:1 $(\mu \mathrm{M})$ therefore proved optimum for maximum regeneration. This requirement might have resulted from the use of $1 \mathrm{mg} \mathrm{L}^{-1} 2,4-\mathrm{D}$ during callus induction and cell suspension steps. Auxin 2,4.D is eight to twelve times the activity of IAA (Engvild, 1978) and it may also cause 

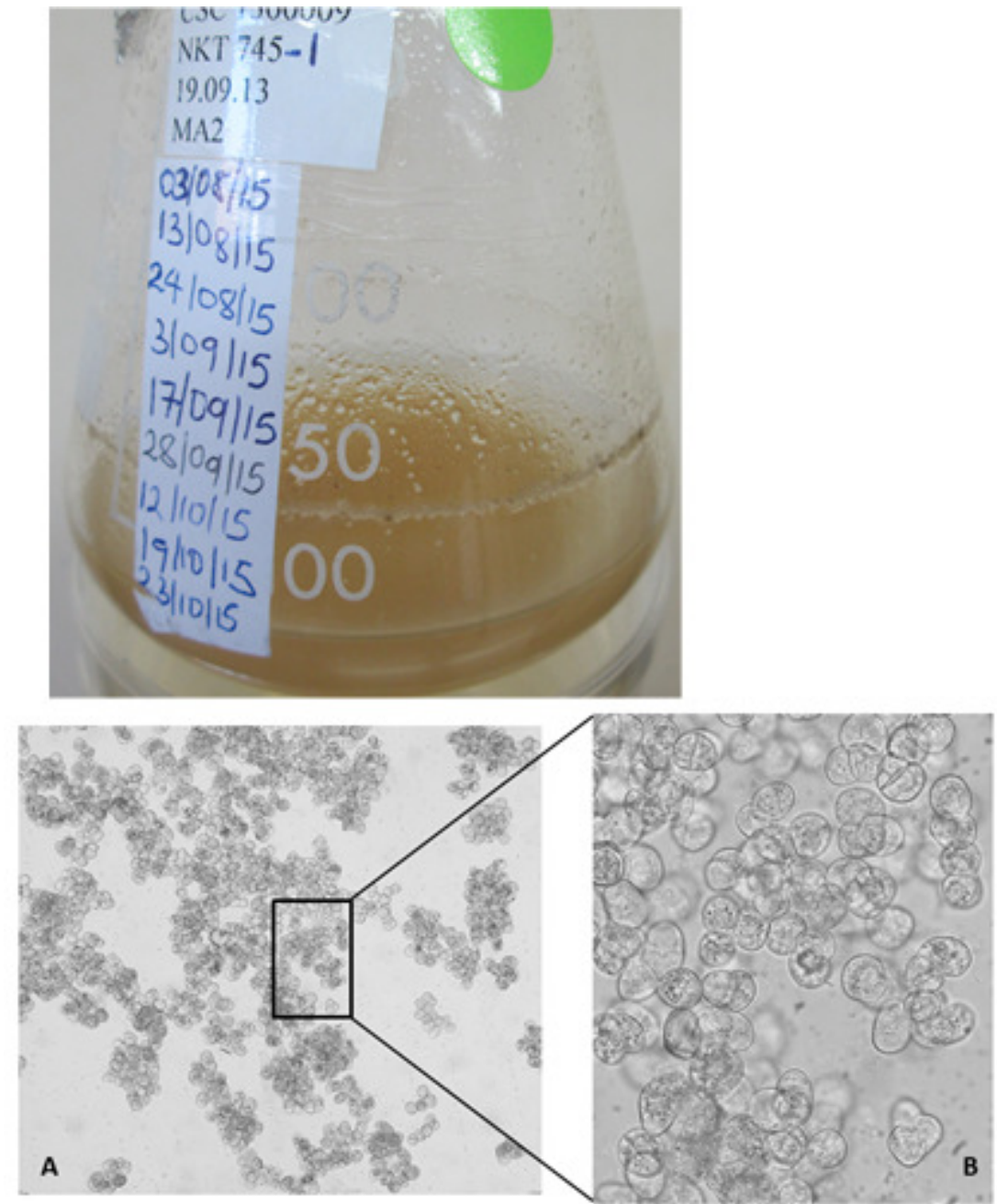

Figure 1. Cell dispersion in suspension medium of banana cv "Nakitembe", cell line 745. Below: Actively dividing cells as observed under light microscope at 400x magnification (A); Close up of the cells (B).

a carry over effect (George, 1993). In addition, studies of highland bananas demonstrated a higher biosynthesis of natural auxins in relation to cytokinins (Talengera et al., 1994). Therefore, the resultant endogenous auxin in the cells might have required a counter balance of higher BAP concentration to trigger organogenesis (Pierik, 1987; George, 1993). Regeneration of the oldest cell line 660 was consistently low under the different growth regulator combination (Fig. 2). Habituation could have arisen where the long exposure of cells to exogenous auxin induce their biosynthesis in the cells (George, 1993). This phenomenon can partly explain the benefit of old cell lines to high BAP.

\section{CONCLUSION}

This study has achieved induction of embryogenic callus as the critical stage of somatic embryogenesis of cultivar "Nakitembe" at $10.2 \%$. The efficiency of converting the cell suspension into plantlets was increases by $83 \%$, comparable to other Musa genotypes. This breakthrough has 


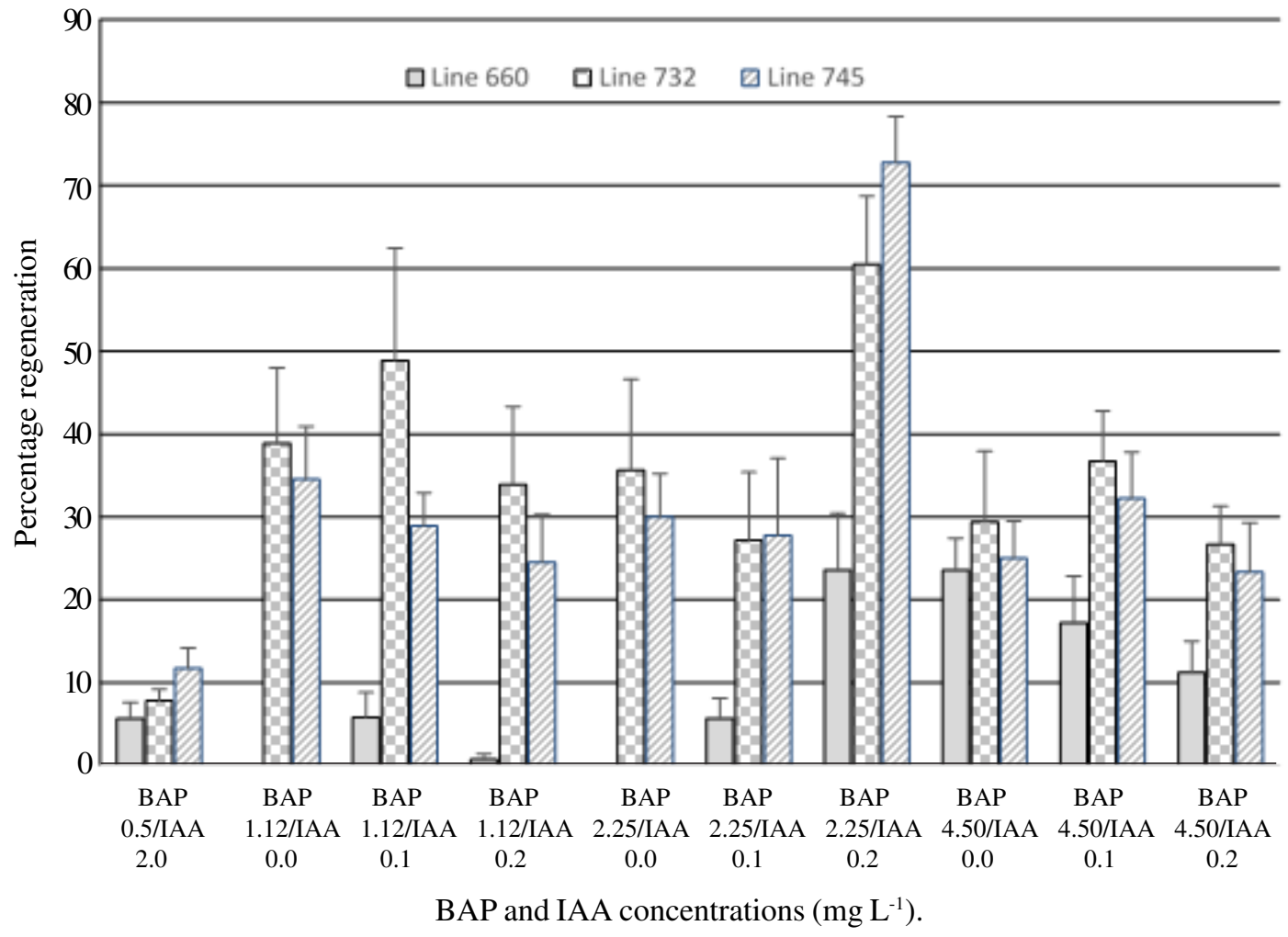

Figure 2. Variation of shoot regeneration capacity of three highland banana embryos derived from cell lines of different age in culture. Embryo germination medium was fortified with different BAP and IAA concentrations. Concentration of BAP at 0.5 and IAA at $2.0 \mathrm{mg} \mathrm{L}^{-2}$ was the control. Columns and bars represent means and standard errors, respectively.
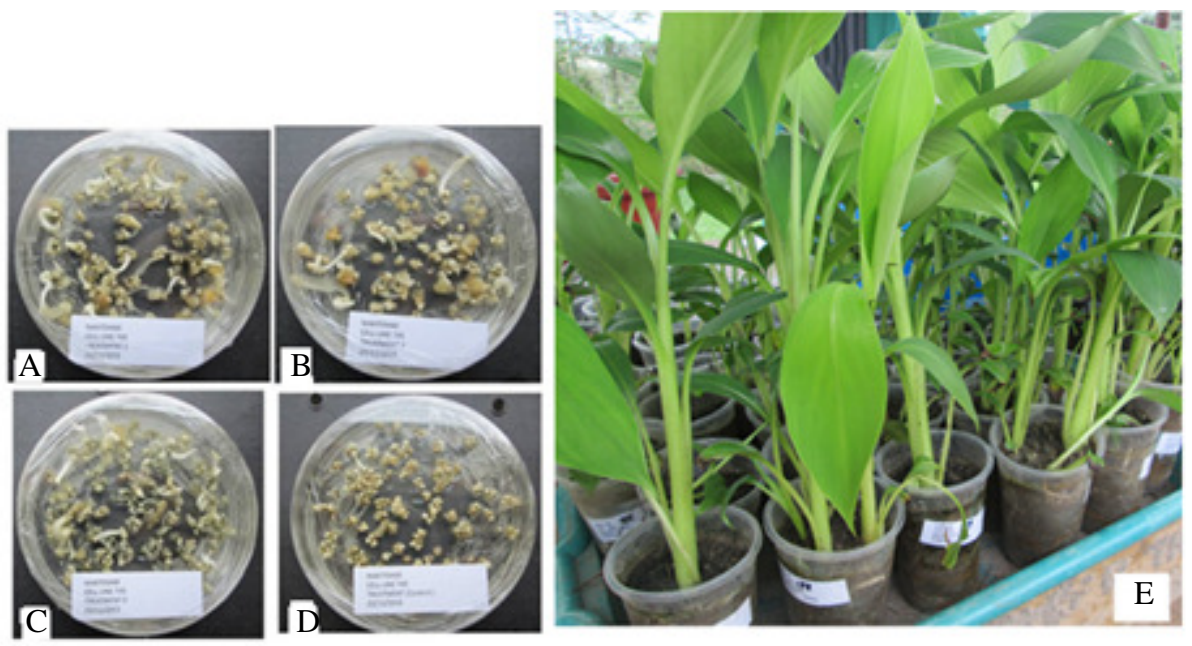

Figure. 3. Representative plates of banana cv "Nakitembe" embryos germinating on MA4 medium containing different BAP and IAA combinations in $\left(\mathrm{mg} \mathrm{L}^{-1}\right)$ : (A): BAP (1.12) and IAA (0.0); (B) BAP (1.12) and IAA (0.1); (C): BAP (2.25) and IAA (0.2); and (D) Control: BAP (0.05) and IAA (0.2); (E) Plantlets regenerated from cell line 745. 
provided a platform for genetic engineering "Nakitembe" for weevil, nematode resistance and nutritional improvement. But it will also be beneficial to maintain such precious embryogenic cells at minimum metabolic conditions under cryopreservation instead of cell suspensions. This strategy will reduce the risks of somaclonal variation, contamination as well as loss of embryogenesis and regenerative capacity.

\section{ACKNOWLEDGMENT}

This research was funded by Bioversity International and the Government of Uganda to the National Agricultural Research Organization under the collaborative project: Novel Approaches to the Improvement of Banana Production in Eastern Africa-the application of biotechnological methodologies. We are grateful to Dr. Jerome Kubiriba, Dr. Wilberforce K. Tushemereirwe and Dr. Eldad Karamura for their project administrative roles. We also thank Mr. Fred Kizito for maintaining the banana fields that provided the male buds and Ms. Doreen Amumpaire for maintaining the cell suspensions.

\section{REFERENCES}

Ali, H.M., El-Gizawy A.M., El-Bassiouny, R.E.I. and Saleh, M.A. 2015. Browning inhibition mechanisms by cysteine, ascorbic acid and citric acid, and identifying PPO-catechol-cysteine reaction products. Journal of Food Science Technology 52(6):3651-3659. doi: 10.1007/s13197014-1437-0.

Arinaitwe, G., Remy, S., Strosse, H., Swennen,R. and Sagi. L. 2004. Agrobacterium- and particle bombardmentmediated transformation of a wide range of banana cultivars. In: Jain, S.M. and Swennen, R. (Eds.). Banana Improvement: Cellular, Molecular Biology and Induced Mutation pp. 351-357.
Chu, C.C., Wang, C.C., Sun, C.S., Hsu, C., Yin, K.C., Chu, C.Y. and Bi, F.Y. 1975. Establishing of an efficient medium for anther culture of rice through comparative experiments on nitrogen sources. Science Sinica 18:659-668.

Dai, S., Zheng, P., Marmey, P., Zhang, S., Tian, W., Chen, S., Beachy,R.N. and Fauquet, C. 2001. Comparative analysis of transgenic rice plants obtained by Agrobacterium-mediated transformation and particle bombardment. Molecular Breeding 7:25-33.

Elayabalan, S., Kalaiponmani, K., Pillay, M., Chandrasekar, A., Selvarajan, R., Kumar,K. K. and Balasubramanian, P. 2013. Efficient regeneration of the endangered banana cultivar 'Virupakshi' (AAB) via embryogenic cell suspension from immature male flowers. African Journal of Biotechnology 12(6):563-569.

Engvild, K.C. 1978. Substituted indolacetic acids tested in tissue cultures. Physiologia Plantarum 44:345.

George, E.F. 1993. Plant propagation by tissue culture. Part 1: The technology. Exegentics Ltd.

Hu, C-X., Zou,R., Pan,X. and Chen, H-B. 2008. Somatic embryogenesis in banana (Musa spp). International Journal of Plant Developmental Biology 2(1):52-58.

Karamura, D. 1999. Numerical taxonomic studies of the East African highland bananas (MusaAAA-EA) in Uganda. INIBAP, France. 192pp.

Khalil, S.M., Cheah, K.T., Perez, E.A., Gaskill, D.A. and Hu, J.S. 2002. Regeneration of banana (Musa spp. AAB cv Brazilian) via secondary somatic embryogenesis. Plant Cell Reports 20:1128-1134. doi: 10.1007/ s00299-002-0461-0

Murashige, T. and Skoog, F. 1962. A revised medium for rapid growth and bio-assays with tobacco tissue cultures. Physiologia Plantarum 15:473-497. 
Namanya, P., Magambo, S.M., Mutumba,G. and Tushemereirwe, W. 2004. Somatic embryogenesis from immature male inflorescences of East African highland banana cv. "Nakyetengu". African Crop Science Journal 12(1):43-49.

Nowakunda, K., Barekye, A., Ssali, R.T., Namaganda, J., Tushemereirwe, W.K., Nabulya, G., Erima, R., Akankwasa, K. and Hilman, E. 2015. 'Kiwangaazi' (syn 'KABANA 6H') black sigatoka nematode and banana weevil tolerant 'Matooke' hybrid banana released in Uganda. Hortscience 50(4):621-623.

Pierik, R.L.M. 1987. In vitro culture of higher plants. Martinus Nijhoff. 344pp.

Pillay, M., Ssebuliba, R., Hartman, J., Vuylsteke, D., Talengera, D. and Tushemereirwe, K. 2004. Conventional breeding strategies to enhance the sustainability of Musa biodiversity conservation for endemic cultivars. African Crop Science Journal 12(1):59-65.

Sharma, P., Jha, A.B., Dubey, R.S. and Pessarakli, M. 2012. Reactive oxygen species, oxidative damage, and antioxidative defense mechanism in plants under stressful conditions. Journal of Botany 127. doi:10.1155/2012/217037.

Ssebuliba, R., Talengera, D., Makumbi, D., Namanya, P., Tenkouano, A., Tushemereirwe, W. and Pillay, M. 2006. Reproductive efficiency and breeding potential of East African highland (Musa AAA-EA) bananas. Field Crops Research 95:250-255.doi:10.1016/j.fcr.2005.03.004.
Strosse, H., Domergue, R., Panis, B., Escalant, J.V. and Côte, F. 2003. Banana and plantain embryogenic cell suspensions, Vézina, A. and Picq, C. (Eds.). INIBAP Technical Guidelines 8. Montpellier, France. $31 \mathrm{pp}$.

Talengera, D., Magambo,M.J.S. and Rubaihayo, P.R. 1994. Testing for a suitable culture medium for micropropagation of East African highland bananas (Musa spp.). African Crop Science Journal 2(1):17-21.

Tumuhimbise, R., Buregyeya, H., Barekye, A., Ssali, R.T., Talengera, D., Kubiriba, J., Muhangi, S., Namagembe, B., Namanya, P., Arinaitwe, G., Tushemereirwe, W.K., Karamura,D.and Karamura, E. 2016. Selection of cooking banana genotypes for yield and black Sigatoka resistance in different locations in Uganda. Journal of Plant Breeding and Crop Science. 8(5):6071. doi: 10.4236/as.2020.1111066

Xu, C-H., Zou, R., Pan, X. and Chen, H-B. 2008. Somatic embryogenesis in banana (Musa spp). International Journal of Plant Developmental Biology 2(1):52-58.

Youssef, M., James, A., Mayo-Mosqueda, A., Ku-Cauich, J., Grijalva-Arango, R. and Escobedo, G.M. 2010. Influence of genotype and age of explant source on the capacity for somatic embryogenesis of two Cavendish banana cultivars (Musa acuminata Colla, AAA). African Journal of Biotechnology 9(15):2216-2223. 